\title{
verals
}

ISSN 2236-5729

\section{Quando o calendário se transforma em relógio: as datas comemorativas no planejamento escolar}

\section{When the calendar turns into a clock: \\ commemorative dates in school planning}

Núbia de Oliveira Santos é Pedagoga e Doutora em Educação pela Universidade do Estado do Rio de Janeiro. Especialista em Educação Infantil pela Pontifícia Universidade Católica do Rio de Janeiro. Professora da Faculdade de Educação da Universidade Federal do Rio de Janeiro.

\section{Contato: nnubia@terra.com.br}

Rita Marisa Ribes Pereira é Licenciada em Filosofia pela Universidade Federal de Pelotas e Doutora em Ciências da Educação pela Pontifícia Universidade do Rio de Janeiro. Professora da Faculdade de Educação da Universidade do Estado do Rio de Janeiro. Coordenadora do Grupo de Pesquisa Infância e Cultura Contemporânea. Procientista UERJ/FAPERJ e Bolsista de Produtividade do CNPq.

\section{Contato: ritaribes@uol.com.br}

\section{Resumo}

Este texto propõe uma reflexão sobre as datas comemorativas no planejamento escolar. 0 caminho escolhido é o da formulação de questões sobre essa prática conduzida pela tese de que o trabalho com as datas comemorativas coloca em pauta conceitos de tempo, de história e de cultura. Que relações o calendário escolar com suas datas comemorativas convencionadas dialoga com o calendário da vida social e cultural mais ampla? Em que medida essa relação fertiliza o diálogo entre escola e cultura? Em que medida esteriliza aspectos da cultura ao reduzilos a conteúdo escolar? Santo Agostinho, Walter Benjamin, Edward Hall, Caroline Queiroz, Jeanne-MarieGagnebin, Sonia 
Kramer e Luciana Ostetto, entre outros autores, ajudam a fundamentar as indagações aqui compartilhadas.

Palavras-chave: planejamento escolar; datas

comemorativas; tempo; história; cultura.

\begin{abstract}
This text proposes a reflection about commemorative dates in school planning calendar. We make some questions about this practice, driven by the thesis that working with commemorative dates establishes time, history, and cultural concepts. What relations does the school calendar, with its conventional commemorative dates, establish with a broader social and cultural calendar? Furthermore, how does this relationship enhance the dialogue between school and culture? And above all, to what extent does it reduce the cultural aspects by limiting them to school content? Authors such as Saint Augustine, Walter Benjamin, Edward Hall, Caroline Queiroz, Jeanne-Marie Gagnebin, Sonia Kramer, and Luciana Ostetto, among others, help to substantiate the questions shared here.

Key words: School planning; Commemorative dates; Time; History; Culture
\end{abstract}

\title{
Introdução
}

Carnaval. Dia Internacional da Mulher. Páscoa. Dia do Índio. Tiradentes. Dia do Trabalhador. Dia das Mães. Abolição da Escravatura. Dia do Meio Ambiente. Festa Junina. Dia da Vovó. Dia dos Pais. Dia do Folclore. Dia do Soldado. Independência do Brasil. Dia da Árvore. Festa da Primavera. Semana do trânsito. Dia das Crianças. Dia do Professor. Halloween. Proclamação da República. Dia da Bandeira. Dia da Consciência Negra. Natal. Carnaval. Dia Internacional da Mulher. Páscoa. Dia do Índio. Tiradentes. Dia do Trabalhador. Dia das Mães. Abolição da Escravatura. Dia do Meio Ambiente. Copa do Mundo na África do Sul. Festa Junina. Dia da Vovó. Dia dos Pais. Dia do Folclore. Dia do Soldado. Independência do Brasil. Dia da Árvore. Festa da Primavera. Semana do trânsito. Dia das Crianças. Dia do Professor. Eleições. Halloween. Proclamação da República. Dia da Bandeira. Dia da Consciência Negra. Natal. Carnaval. Dia Internacional da Mulher. Páscoa. Dia do Índio. Tiradentes. Dia do Trabalhador. Dia das Mães. Abolição da 
Escravatura. Dia do Meio Ambiente. Festa Junina. Dia da Vovó. Dia dos Pais. Dia do Folclore. Dia do Soldado. Independência do Brasil. Dia da Árvore. Festa da Primavera. Semana do trânsito. Dia das Crianças. Dia do Professor. Halloween. Proclamação da República. Dia da Bandeira. Dia da Consciência Negra. Natal. Carnaval. Dia Internacional da Mulher. Páscoa. Dia do Índio. Tiradentes. Dia do Trabalhador. Dia das Mães. Abolição da Escravatura. Dia do Meio Ambiente. Festa Junina. Dia da Vovó. Olimpíadas de Londres. Dia dos Pais. Dia do Folclore. Dia do Soldado. Independência do Brasil. Dia da Árvore. Festa da Primavera. Semana do trânsito. Dia das Crianças. Dia do Professor. Eleições. Halloween. Proclamação da República. Dia da Bandeira. Dia da Consciência Negra. Natal. Carnaval. Dia Internacional da Mulher. Páscoa. Dia do Índio. Tiradentes. Dia do Trabalhador. Dia das Mães. Abolição da Escravatura. Dia do Meio Ambiente. Festa Junina. Dia da Vovó. Dia dos Pais. Dia do Folclore. Dia do Soldado. Independência do Brasil. Dia da Árvore. Festa da Primavera. Semana do trânsito. Dia das Crianças. Dia do Professor. Halloween. Proclamação da República. Dia da Bandeira. Dia da Consciência Negra. Natal. Carnaval. Dia Internacional da Mulher. Páscoa. Dia do Índio. Tiradentes. Dia do Trabalhador. Dia das Mães. Abolição da Escravatura. Dia do Meio Ambiente. Copa do Mundo no Brasil. Festa Junina. Dia da Vovó. Dia dos Pais. Dia do Folclore. Dia do Soldado. Independência do Brasil. Dia da Árvore. Festa da Primavera. Semana do trânsito. Dia das Crianças. Dia do Professor. Eleições. Halloween. Proclamação da República. Dia da Bandeira. Dia da Consciência Negra. Natal. Carnaval. Dia Internacional da Mulher. Páscoa. Dia do Índio. Tiradentes. Dia do Trabalhador. Dia das Mães. Abolição da Escravatura. Dia do Meio Ambiente. Festa Junina. Dia da Vovó. Dia dos Pais. Dia do Folclore. Dia do Soldado. Independência do Brasil. Dia da Árvore. Festa da Primavera. Semana do trânsito. Dia das Crianças. Dia do Professor. Halloween. Proclamação da República. Dia da Bandeira. Dia da Consciência Negra. Natal. Carnaval. Dia Internacional da Mulher. Páscoa. Dia do Índio. Tiradentes. Dia do Trabalhador. Dia das Mães. Abolição da Escravatura. Dia do Meio Ambiente. Olimpíadas no Brasil. Festa Junina. Dia da Vovó. Dia dos Pais. Jogos Olímpicos do Rio de Janeiro. Dia do Folclore. Dia do Soldado. Independência do Brasil. Dia da Árvore. Festa da Primavera. Semana do trânsito. Dia das Crianças. Dia do Professor. Eleições. Halloween. Proclamação da República. Dia da Bandeira. Dia da Consciência Negra. Natal. Carnaval. Dia Internacional da Mulher. Páscoa. Dia do Índio. Tiradentes. Dia do Trabalhador. Dia das Mães. Abolição da Escravatura. Dia do Meio Ambiente. Festa Junina. Dia da Vovó. Dia dos Pais. Dia do Folclore. Dia do Soldado. Independência do Brasil. Dia da Árvore. Festa da Primavera. 
Semana do trânsito. Dia das Crianças. Dia do Professor. Halloween. Proclamação da República. Dia da Bandeira. Dia da Consciência Negra. Natal. Carnaval. Dia Internacional da Mulher. Páscoa. Dia do Î́ndio. Tiradentes. Dia do Trabalhador. Dia das Mães. Abolição da Escravatura. Dia do Meio Ambiente. Copa do Mundo na Rússia. Festa Junina. Dia da Vovó. Dia dos Pais. Dia do Folclore. Dia do Soldado. Independência do Brasil. Dia da Árvore. Festa da Primavera. Semana do trânsito. Dia das Crianças. Dia do Professor. Eleições(?). Halloween. Proclamação da República. Dia da Bandeira. Dia da Consciência Negra. Natal.

Uma década contada a partir de uma sequência de datas comemorativas que hegemonicamente compõem o calendário escolar. Prática muitas vezes naturalizada no cotidiano que quando exposta por escrito na abertura deste texto, provoca (assim esperamos) um certo estranhamento. Transformar esse estranhamento em questões para pensar a prática pedagógica é o propósito principal deste texto. Que projetos de vida estão em jogo quando organizamos o planejamento escolar? Como as datas comemorativas se transformam numa estratégia/metodologia para estruturar esse planejamento? Que concepções de tempo, de história e de cultura estamos construindo quando optamos por essa forma de organização do planejamento escolar? Que significa reger a vida escolar a partir de datas comemorativas? Que datas? Por que essas e não outras? Qual a origem dessas datas e em que contextos adentram o currículo? Que relações de poder as cercam? 0 que as tornam memoráveis e comemoráveis? Quais suas relações com a cultura e com os sujeitos que dão vida à comunidade escolar - crianças, famílias, professores, servidores? Quais suas relações com o consumo? Enfim, são muitas as perspectivas a partir das quais podemos formular indagações sobre essa prática. Neste texto, porém, queremos propor um questionamento a partir das concepções de tempo, de história e de cultura que subjazem à opção pelo uso das datas comemorativas como condutoras da prática pedagógica.

\section{Tempo, história, cultura}

Como perceber o tempo? Como explicá-lo? Talvez a famosa ponderação feita em fins do Século IV por Santo Agostinho (1973) nas suas Confissões traduza a complexidade dessa tarefa:

Que é, pois, o tempo? Quem poderá explicá-lo clara e brevemente? Quem o poderá apreender, mesmo só com o pensamento, para depois nos traduzir por palavras o seu conceito? 
E que assunto mais familiar e mais batido nas nossas conversas do que o tempo? Quando dele falamos, compreendemos o que dizemos. Compreendemos também o que nos dizem quando dele nos falam. 0 que é, por conseguinte, o tempo? Se ninguém me perguntar eu sei; se o quiser explicar a quem me fizer a pergunta, já não sei.

Dezessete séculos passados das ponderações feitas por Santo Agostinho e contando hoje com uma extensa literatura acumulada sobre o tema, a complexidade parece persistir. Quando organizamos nosso planejamento escolar, lá está ele, o tempo. Estará familiar e batido nas conversas, supostamente compreendido quando dele se fala?Se quisermos, hoje, explicá-lo, apreendê-lo, traduzir em palavras o seu conceito, saberemos? Que é o tempo? Almejamos, ainda, explicá-lo? Em que medida o percebemos? Ou terá se tornado invisível, alheio às percepções humanas? 0 tempo é, de fato, hoje, para nós, uma questão?

Encontramos nos estudos de Caroline Trapp Queiroz (2018) a afirmação de que a percepção e as formas de lidar com o tempo são uma construção humana, isto é, o tempo é uma experiência humana. Mesmo Santo Agostinho o compreendia nos limites da criação do universo, diferenciando-o da ideia de eternidade que teria um caráter divino. Ao longo da história, a humanidade vem ensaiando formas de sentir, de medir e de marcar a experiência do tempo. Trata-se de um processo de subjetivação extremamente complexo cuja compreensão conta com diversificadas formas de abordagem.

A invenção dos calendários e dos relógios são instrumentos que falam do esforço humano de marcar o tempo e suas transformações. Ao longo da história foram se transformando conforme o significado do tempo nas diferentes culturas. Tendo sua origem historicamente ligada aos povos sumérios da Mesopotâmia do Século XXVII a. C., os primeiros calendários tinham por critério a marcação lunar de doze ciclos com cerca de 29 ou 30 dias cada, totalizando um ano com 354 dias. Os ciclos lunares originários, no entanto, não coincidiam com os ciclos solares e demandavam periódicas contas de ajuste.

Dentre esses ajustes talvez o mais radical tenha sido a mudança do calendário juliano, de orientação luminosolar, criado no século IV a. C. pelo Imperador Romano Julio Cesar, para o calendário gregoriano, impetrado pelo Papa Gregório III em fins do Século $\mathrm{XVI}$, com pretensão de universalização do ano civil entre as nações, posto que havia uma defasagem entre o ano social e o ano 
religioso. Tais ajustes não se limitam apenas a critérios de precisão, mas também a relações geopolíticas, culturais e religiosas. Alguns países o adotaram de imediato, outros permaneceram reticentes e houve aqueles que até mesmo criaram um terceiro calendário de ajuste até que se chegasse à internacionalização de caráter civil pretendida que, efetivamente, somente acontecerá no século XX (Queiroz, 2018).

De convenções como a inscrição do nascimento de Cristo como marco do ano I do calendário ocidental à universalização internacionalização de um calendário civil marcado pela globalização dos mercados e da cultura contemporânea, muitas outras formas de marcar o tempo e disputar as narrativas sobre a sua experiência foram se atravessando: o calendário judaico, o calendário muçulmano, o calendário chinês, são exemplares dessa multiplicidade.

Segundo Elias (1998), o desenvolvimento do calendário caracteriza o desenvolvimento em longo prazo do conhecimento humano; seria ele como [...] o modelo empírico reduzido de uma corrente evolutiva que perpassa toda uma sucessão de sociedades, que abrange períodos históricos delimitados (ELIAS, 1998, p.152). 0 tempo marcado pelos calendários ilustra a pertença do indivíduo a uma realidade social; é a partir do calendário que o homem pode precisar o ponto em que ele mesmo se insere no fluxo dos processos físicos e sociais.

Assim como os calendários, também os relógios são formas historicamente construídas para marcar o tempo e partilhar pactuações culturais a seu respeito. Considera-se que os primeiros relógios surgiram entre os babilônios e egípcios por volta do Século XVI a.C. Inicialmente baseavam-se em projeções de sombras orientadas pelo movimento do sol, o que restringia sua funcionalidade aos períodos diurnos. Posteriormente aos chamados relógios de sol outras formas surgiram: relógios de água, ampulhetas ou relógios de areia. Supõe-se que os primeiros relógios mecânicos surgiram por volta do século XVI, mas se popularizaram somente no contexto da Revolução Industrial. 0 Século XX espalhou grandes relógios em fábricas, prédios públicos e torres nos grandes centros urbanos, tratou de colocá-los nos pulsos das pessoas e a "hora certa" passa a ser um guia para o ritmo da vida e do trabalho. A busca de precisão orientou a especialização: de correias dentadas, pêndulos, corda, átomos às tecnologias digitais, o que liga os seres humanos que hoje leem as horas no celular àqueles que um dia buscaram medir o tempo com 
a luz do sol? Quantas culturas nasceram e desaparecem ao longo desse processo? Quantos aspectos da vida se tornaram comuns a partir delas?

Sugerindo os estudos de Queiroz (2018) para um maior aprofundamento, apresentaremos aqui, de forma breve, algumas formas de abordagem já sistematizadas, mais no intuito de abrir um leque de possibilidades de questionamentos do que para exaurir cada uma delas. Com isso, queremos reforçar que nossa intenção é que a temática do tempo torne-se uma questão, pois, no contexto escolar, muitas vezes ela só se torna perceptível quando elencada entre os conteúdos a serem ensinados às crianças. No entanto, se o tempo atravessa a própria vida e a compõe, há que prestar atenção nas maneiras como ele atravessa a experiência da escola, tanto para as crianças, quanto para os adultos. Que é o tempo na escola? De que formas o percebemos? Como lidamos com ele? Que experiências com tempo são possíveis na escola?

Cotejando a complexidade que envolve a temática do tempo,Queiroz (2018) cita a sistematização feita pelo antropólogo Edward Hall (apud Queiroz, 2018) que elenca nove formas distintas de lidar com o tempo que se entrecruzam numa mandala: o tempo sagrado, o tempo profano, o microtempo, a sincronia, o tempo individual, o tempo biológico, o tempo físico, o tempo metafísico e o metatempo. Talvez se mostre mais claramente para nós a experiência do tempo profano que, na perspectiva do autor, corresponde ao modo cotidiano de lidar com o tempo, aquele que permeia o fluxo cotidiano da vida. No entanto, sua própria nomeação como profano implica pensá-lo em diálogo ou mesmo contraposição com o tempo sagrado, aquele ligado a uma suspensão no fluxo cotidiano para viver uma experiência do sagrado - experiência essa que se confunde com uma suspensão do próprio tempo. Como microtempo, a terceira forma citada, o autor classifica as formas já absorvidas da cultura nos modos de lidar com o tempo, que incluem as formas de viver já tornadas hábito na cultura a que pertencemos. Justamente por isso o tempo age como se fosse um participante oculto na organização da vida. Ligado a esta forma, Hall (apud Queiroz, 2018) fala da sincronia que, diferentemente, implicaria numa postura consciente do ser humano de buscar ajustar a temporalidade da sua vida individual com a vida coletiva. A sincronia, por sua vez, abre espaço para a quinta forma de percepção do tempo descrita por Hall: o tempo individual, que estaria ligado à forma como cada um, nas suas percepções pessoais, sente o tempo, como um tempo interior. 
O tempo biológico é descrito por Hall como aquela experiência que é ditada pelos elementos da natureza, seja dos órgãos vitais em cada um de nós, seja na relação com as marés, as estações do ano, ou as diferentes formas de vida do planeta. Uma sétima forma de percepção do tempo, o tempo físico, é descrita por Hall como aquela que se torna possível a partir dos movimentos do universo - a particularidade de entender que a estrela que contemplamos no céu pode não mais estar viva uma vez que entre o olhar que lançamos a ela, de nosso planeta, e ela, existe não apenas um espaço, mas também um tempo que se estendem de formas distintas. Em contraponto, o tempo metafísico é o tempo das experiências suprassensíveis, o tempo que não se pode provar justamente porque é do campo do ocultismo, mas que instaura uma lógica particular. Por último, o conceito de metatempo estaria ligado ao fato de que, embora cada um dos tipos apresentados impliquem em uma lógica própria, há um outra forma de tempo que é a forma de estudar o próprio tempo, de se relacionar com ele na sua multiplicidade de formas, sem perder de vista que a atividade de estudar, sistematizar, classificar, compreender etc. coloca em cena também uma forma particular de tempo que, ao cotejar as demais, não pode impor sua lógica, nem subsumir-se nas demais. Traduzindo, de forma simples: é preciso tempo para estudar a temática do tempo. Um tempo de muitos tempos.

Para destacar ainda mais a complexidade que envolve a temática do tempo, podemos cotejar a mandala contemporânea de Edward Hall que apresenta diferentes formas de compreender o tempo com a clássica forma utilizada pelos antigos gregos que recorriam a três termos distintos para designar o tempo: cronos, kayrose aión. Na sistematização feita por Gagnebin (1997), o tempo cronos estaria mais ligado ao tempo físico e às possibilidades de medir o seu movimento, por assim dizer, delimitado no âmbito da quantificação e da vontade de controle; o tempo kayrós, por sua vez, seria o tempo da intensidade, da oportunidade, o tempo da comunhão entre o imprevisível e o decisivo, marcado pelo caráter da qualificação. Já o tempo aión estaria mais ligado ao campo do sagrado, da longa duração, do porvir e, paradoxalmente, seu caráter está justamente em ser atemporal. Embora distintos, podem cotejar-se, e dessa distinção, pondera Gagnebin (1997), o que se explicita é a própria multiplicidade do tempo e das formas de percebê-lo.

A mandala construída por Hall (apud Queiroz, 2018), por exemplo, é fruto de um esforço de reconhecer e diferenciar modos de perceber e sistematizar a experiência do tempo, e também de 
buscar semelhanças, subdivisões e novas composições entre os tempos catalogados. Do mesmo modo, Gagnebin (1997) pondera sobre como os atravessamentos das concepções de tempo nas suas vertentes cronos, kairós e aión implicam rasuras nas lógicas de cada um. Ressalta-se que na vida cotidiana esses atravessamentos entre os diferentes tempos acabam por aproximar ou cindir diferentes aspectos da vida humana - o individual e o coletivo, a natureza e a cultura, o sagrado e o profano, os hábitos e as eventualidades. Como o tempo da natureza se relaciona com o tempo da cultura? 0 que há de coletivo no tempo individual? Que é quantidade e qualidade em relação ao tempo? Como os ciclos da vida social se desenham nos calendários? Como as efemérides cronologicamente marcadas podem se transformar em blocos de tempo com intensidades variadas?

A teoria da relatividade do tempo que se finaliza nos estudos de Einstein no início do Século XX, por seu turno, foi de extrema relevância não apenas para os estudos sobre o tempo específicos do campo da Física, como também para ressignificar a própria indagação sobre o tempo, que passou a incluir não apenas o tempo como objeto de estudo, mas também o espaço e o sujeito que os percebe como elementos decisivos para a relativização. Um exemplo clássico para ilustrar tal teoria é a de que um astronauta que permaneça no espaço por um certo tempo, ao voltar não terá envelhecido na mesma proporção que os seus amigos que ficaram na Terra. Ou seja, o tempo vivido na Terra e o tempo vivido no espaço, embora supostamente iguais, são vividos diferentemente, sendo o tempo, portanto, relativo.

Essa relação imbricada de tempo e espaço tal como definida por Einstein é decisiva para o modo como o filósofo Mikhail Bakhtin (2003) pensará o papel da linguagem nas relações humanas e na criação estética - mais especificamente a literatura. Bakhtin constrói o conceito de cronotopo a partir da relação indissolúvel entre tempo e espaço. Para o autor, o tempo seria a quarta dimensão do espaço, de modo que não existiriam separadamente. Pensar o tempo associado ao espaço permite, ainda, dar visibilidade ao tempo, para que dele possa se tomar consciência e torná-lo objeto de crítica. Todo acontecimento, diz Bakhtin, tem por solo um tempo e um espaço próprios e estes são decisivos para as condições e para as possibilidades de linguagem.

Assim, o tempo é pensado na relação com o espaço em que é vivido, do mesmo modo que o espaço "habitado" não existe esvaziado do tempo vivido. Assim, o breve instante tiquetaqueado 
pelo relógio ou o planejamento/registro da vida na forma de calendário são acontecimentos ético-políticos onde se disputam sentidos para o tempo. Que efemérides compõem o calendário de uma determinada cultura? 0 que esse calendário conta do diálogo e do confronto com outras culturas? Tempo e espaço determinam formas de viver e de narrar o que é vivido. Por conseguinte, as formas de narrar implicam condições determinadas de tempo e espaço. Aí se revela a dimensão política do tempo e do espaço, pois, se determinam as possibilidades do narrar, tornam visíveis as relações de poder que se desenham nas determinações do tempo e do espaço.

Tomando a atividade criadora como foco, Bakhtin traz para o debate a dimensão ética que constituem tempo e espaço, como construções humanas. Não são unidades vazias, mas dotadas de sentido, plásticas à materialidade e às contradições da vida. Como são determinados tempo e espaço? 0 que temos a dizer? Em que espaço isso pode ser dito? Que tempo é necessário para o dizer? Tais questões permitem ver a complexidade que liga o viver ao narrar, o individual ao coletivo, o tempo à história.

Walter Benjamin (1987), filósofo alemão que viveu na virada do Século XIX para o XX, é um autor que também se dedicou a aprofundar as estreitas relações entre tempo e história. Para ele, o modo como a história é narrada é decisivo para a construção da percepção humana do tempo. 0 tempo vivido pelo artesão e as narrativas nascidas no contexto coletivo desse seu trabalho são qualitativamente diferentes daquele vivido na esteira da produção em série, contexto de trabalho massificado onde a narrativa atrapalha a produção. Benjamin, assim como Bakhtin, está marcando o caráter histórico do tempo, que varia conforme os determinantes sociais, culturais e de época. Varia também de acordo com quem sistematiza e narra a história. E quem narra a história? Os vencedores, diz Benjamin (1987). Assim têm sido. E sua narrativa não tem por objetivo que os homens se reconheçam na história narrada, que a reconheçam como narrativa da história vivida. Ao contrário, interessa aos vencedores que os sujeitos da vida comum não se sintam parte da história narrada, menos ainda que almejem serem seus narradores.

Que consequências éticas resultam disso? Uma história homogênea e vazia, um salpicado de fatos fragmentários contados de forma heroica. Com a Revolução Industrial e os avanços científicos que a ela se somaram, o autor observa ter havido como que uma aceleração do ritmo da vida, que passa a se orientar pela lógica da produção, característica do mundo capitalista. 0 filme 
Tempos Modernos, de Charles Chaplin, parece exemplar para falar dessa relação na qual a linha de montagem exige de nós uma atenção autômata e, com isso, dificulta a percepção do tempo e da história, expropriando-nos dela. Essa aceleração faz com que as relações que se tem com o presente pareçam independentes do passado e do futuro. Para falar dessa aceleração, Benjamin (1987) recorre a um quadro pintado por Paul Klee intitulado Angelus Novus, o anjo da História. Olhos esbugalhados, boca dilacerada. Seu desejo seria poder se deter, contemplar o passado, perceber o presente, juntar os cacos e ruínas que se acumulam aos seus pés. Mas a tempestade do progresso, naturalizada numa história linear, o empurra incessantemente para o futuro.

Talvez o anjo anteveja o calendário se transformando em relógio, como asseverava Walter Benjamin. É como se o tempo, que podia se horizontalizar num planejamento de longa duração, abrir-se à repetição cíclica dos eventos culturalmente convencionados, permitir-se ao inusitado, como um calendário ávido por uma nova marcação; é como se, de repente, esse mesmo calendário tivesse se transformado num imenso relógio com ponteiros picadores de agoras, avisando intermitentemente que o tempo está passando, que já estamos atrasados, que precisamos correr... Nesse contexto, o tempo parece escorrer em pingos de minutos de nossas mãos. Como, então, percebê-lo? Como torná-lo objeto de indagáção?

Quem sabe devamos ouvir o conselho dos trabalhadores que no início do Século XX, em distintas cidades e países, puseram-se a atirar pedras e a tentar fazer parar os grandes relógios dispostos nas torres de fábricas e prédios públicos, símbolos do tal novo mundo do trabalho. Imaginar a paralisação do tempo cronológico como abertura para uma intensidade outra da experiência do tempo.

\section{Datas comemorativas na escola: tempo, história ecultura}

Organizar o planejamento escolar significa, por um lado, cotejar a temática do tempo e, por outro, propor uma experiência com o tempo - e, conjuntamente, com a história e com a cultura. Que projetos e atividades compõem o planejamento escolar? Em que medida esse calendário se abre a outras experiências do tempo? Em que condições são pactuados os critérios para lidar com o tempo na escola?

Kramer (1999) em seu clássico livro Com a pré-escola nas mãos: uma alternativa curricular para a educação infantil, já 
considerava a importância de se trabalhar com os temas chamados cíclicos, aqueles que são recorrentes anualmente e comemorados em datas ou períodos específicos e que apresentam em geral, certas festividades consagradas nacionalmente (p.53), pois estes originam-se de festas, eventos ou comemorações periodicamente celebradas, como Carnaval (fevereiro); Páscoa e Dia do Índio (abril); Dia do trabalho e Dia das Mães (maio) etc. Há, ainda, temas gerados por festas e eventos recorrentes, mas que não são anuais, como Eleições e Copa do Mundo, por exemplo. No entanto, esta alternativa de currículo relacionada às datas comemorativas, embora válida, precisa atuar como provocadora de discussões mais amplas, tendo um eixo de continuidade e não atuando com eventos esporádicos. É Fundamental que os temas sejam cada vez mais fruto das ações e interações dos diferentes personagens que fazem e vivem a escola (p.54, grifo nosso).

Do ponto de vista do currículo, de acordo com o que regem as Diretrizes Curriculares Nacionais para Educação Infantil em seu Artigo $9^{\circ}$, as Práticas Pedagógicas devem garantir experiências que propiciem a interação e o conhecimento pelas crianças das manifestações e tradições culturais brasileiras. Nesse sentido, conceber o trabalho com algumas datas comemorativas nas escolas é um uma possibilidade de caminho para propiciar às crianças experiências que evidenciem tradições e manifestações culturais de um povo. Cabe ressaltar, como reconhecem Barbosa e Horn (2008), que manter tradições culturais, cívicas e/ou religiosas é algo fundamental para as crianças pequenas e que precisam constar no currículo. Entretanto as autoras defendem também a importância da construção do sentido (real ou imaginário) dessas práticas e não apenas a sua suposta comemoração, pois corre-se o risco de, como afirmam Barbosa e Oliveira (2016, p.21) comemorar determinadas datas sem avaliar o sentido e o valor formativo dessas comemorações, ou, ainda, da ideia de que apenas o saber do senso comum é o que deve ser tratado com crianças pequenas. Ou seja, a própria experiência proporcionada pela escola pode aniquilar o sentido daquela data, quando não considera a razão que a fez ter sido criada ou a que marco histórico ela esteja atrelada.

Oliveira (2009) colabora para essa linha de discussão quando afirma que as datas comemoradas nas escolas não são simplesmente festejos surgidos do acaso. São costumes, culturas, histórias e identidades preservadas através da memória, do passado reconstruído pelo presente. Para o autor, a memória como história viva e vivida, permanece no tempo, renovando-se. Novas 
interpretações têm levado a ressignificações e reconstruções dos discursos e narrativas que sacralizaram algumas datas ao longo do tempo.

Datas históricas como "o dia da abolição da escravatura" eram festejadas pela escola considerando a princesa Isabel como heroína. Esta representava, portanto, a "libertação" dos negros. Nos dias de hoje esta data foi ressignificada e reconstruída, trazendo o verdadeiro herói que, por muito tempo, fora excluído dos livros que contavam a história brasileira, "Zumbi dos Palmares", havendo, desta forma, o ressurgir de um novo discurso, de um novo paradigma, descentrando a representatividade do sujeito "princesa Isabel" para "Zumbi dos palmares", ou seja, trazendo para o tempo presente histórias verídicas vivenciadas, registradas e guardadas pela memória da população negra. (OLIVEIRA, 2009, p.6)

Nesse sentido, a escola não pode se furtar do seu papel de discutir as transformações sociais que também se refletem nos sentidos das datas comemorativas. Ostetto (2000) questiona a concepção de história que perpassa os critérios de escolhas das datas comemorativas ao tratar do planejamento na Educação Infantil. A autora indaga sobre os princípios que embasam as escolhas das datas para serem trabalhadas em atividades pedagógicas nas quais o planejamento é direcionado pelo calendário a partir do ponto vista dos adultos. Para a autora, no trabalho com as datas comemorativas a escolha é sempre ideológica porque nem todas as datas são comemoradas. Essa perspectiva toma a história como única e verdadeira, ou seja, a história dos heróis, dos vencedores. História que na verdade privilegia uma visão dominante em detrimento de tantas possíveis, ignorando e omitindo, na maioria das vezes as diferentes facetas da realidade (p.182).

Outra crítica apontada por Ostetto (2000) acerca do planejamento baseado nas datas comemorativas se refere à fragmentação dos conhecimentos em que se trabalha numa semana o início da primavera, por exemplo, e na outra o Dia da Criança, o que revela uma forma superficial e descontextualizada de conceber o trabalho com as datas. Um tempo vazio e homogêneo, como diria Walter Benjamin (1987). As contribuições de Ostetto (2000) nos permitem também refletir sobre como se dão as formas de elaboração e a proposição das atividades realizadas. Como bem exemplifica, muitas vezes tratam-se de "trabalhinhos", "lembrancinhas", "dancinhas", atividades destituídas de reflexão por parte do educador que talvez não se 
questione sobre o sentido do que esta sendo proposto para as crianças. Este caminho, continua a autora, coloca o educador no papel de repetidor, na medida em que, salvo algum trabalho que se renova, a mesma experiência se repete, uma vez que as datas se repetem e atuam como pano de fundo. Acerca das implicações pedagógicas dessa opção a autora afirma,

Essa perspectiva torna-se tediosa na medida em que é cumprida ano a ano, o que não amplia o repertório cultural da criança. Massifica e empobrece o conhecimento, além de menosprezar a capacidade da criança de ir além daquele conhecimento fragmentado e infantilizado (OSTETTO, 2000, p.182)

Em outro estudo, Ostetto (2003) sinaliza como o trabalho a partir das datas comemorativas, que repete o modelo das tão conhecidas lembrancinhas e oferece desenhos prontos paras crianças pintarem, pode massificar o trabalho do professor e impedir que este exerça a sua autoria. 0 professor atesta aquela dissociação que venho pontuando entre razão e sensibilidade. Nesta medida, configura-se um apartar-se da alma - a inteireza de ser humano e, assim, de ser professor." (p. 7). Neste caso, poderíamos afirmar, ainda, que a relação do calendário com a cultura se torna artificial.

Maia (2011)investiga em sua dissertação de mestrado a organização do currículo da Educação Infantil em torno das datas comemorativas do calendário civil e religioso. A partir do olhar sobre duas escolas de Educação Infantil em um dos cinco municípios mais populosos em relação à faixa etária de 0 a 6 anos do Estado do Rio de Janeiro, a autora percebeu que esta forma de organização consta na orientação curricular da rede e no planejamento das escolas sendo naturalizada pelos profissionais que não cogitam a possibilidade de não adotá-las no seu trabalho (p. 132).Neste caso, mais acirradamente que no anterior, o recurso às datas comemorativas como eixo estruturador do trabalho torna-se naturalizado.

Ao tratarem da natureza dos trabalhos realizados a partir de datas comemorativas, Gomes e Monteiro (2016) chamam a atenção para a concentração de atividades expostas em determinados meses do ano, o que revela a vinculação das datas comemorativas às aprendizagens. Outra questão apontada pelas autoras diz respeito a alguns dos objetivos dessas atividades, como, por exemplo, decorar o ambiente da instituição, o que muitas vezes nem conta com a participação das crianças. $\mathrm{Na}$ mesma linha está a quantidade do que é exposto para decorar 
o ambiente em determinados meses. Ou seja, na ausência de datas comemorativas em alguns meses, há um declínio de atividades exibidas. Isso revela como as datas se configuram como organizadoras das atividades que os professores realizam com e para as crianças, um calendário com ares de agenda - repleto de deveres e compromissos.

Outro fator importante para se pensar sobre o lugar ocupado pelas datas comemorativas nas escolas é o lugar social reservado às famílias. Muitas datas são vistas como indispensáveis, pois são momentos em que as famílias podem admiraras crianças em situações de protagonismo, de apresentações que causam emoção, como aquelas ligadas ao Dia dos Pais ou das Mães, por exemplo. Segundo Sousa (2000) músicas, danças e representações que são aprendidas nos ensaios das festas, de modo geral, significam esforço e cansaço extra para as professoras. Para as crianças, podem significar algo até menos interessante do que o que fazem no momento (p. 99). Não raro, também a relação da escola com essas datas pode revelar até mesmo a cristalização de conceitos idealizados como, por exemplo, de modelos de famílias, por vezes dissonantes da diversidade presente na nossa sociedade.

Nas comemorações do dia das mães e em situações outras, a escola muitas vezes, parece desconhecer ou desprezar essas diversidades, tratando as crianças e as suas famílias como iguais. Esse descaso é um profundo desrespeito às crianças e as suas famílias e uma incoerência séria na prática pedagógica do educador infantil (SOUSA, 2000, p. 103).

Em que pese o esforço de muitos educadores e equipes em ressignificar essas práticas, Sousa (2000) assevera que o mais importante é que essas festas e comemorações sejam significativas não somente para as crianças, mas também para as práticas pedagógicas dos professores, que precisam estar atentos aos conceitos, atitudes, valores e ideologias que estão sendo educadas.

A concepção de currículo aqui defendida alicerça-se nas ideias de Barbosa e Oliveira (2016). Para as autoras, o currículo não se restringe ao ensino direto. Suas ações vão além das situações organizadas de ensino, as denominadas tarefas, atividades etc. Esta visão considera todas as ações concretizadas no cotidiano e realizadas com a participação das crianças. 0 professor nesse sentido, atua como supervisor dessas ações, é o responsável em oferecer as crianças um ambiente amplo de possibilidades. 
Nessa visão, a transmissão e a reelaboração de conhecimentos socialmente significativos e contextualmente relevantes para as novas gerações estão presentes nos modos dos adultos de organizar e estruturar as práticas pedagógicas considerando as singularidades dos bebês e das crianças pequenas, bem como as diversidades culturais, sociais, etárias e políticas de cada grupo. (BARBOSA e OLIVEIRA, 2016, p.23)

Assim, tal definição de currículo, defendem as autoras, considera e reconhece não somente a intencionalidade da prática pedagógica na organização dos espaços, tempos, materiais, relações sociais, na seleção de experiências de aprendizagem, mas também, e sobretudo, o protagonismo das crianças, levando em conta suas decisões e escolhas e não apenas as dos adultos. 0 currículo é entendido não unicamente como aqueles momentos ou situações formais de ensino, mas coloca professores, gestores e demais profissionais da escola a planejar situações de aprendizagem para além do momento da "atividade dirigida" (p.23).

\section{Considerações finais}

$\mathrm{Na}$ vida cultural de uma sociedade, as datas comemorativas carregam contextos, sejam eles históricos, culturais, comerciais, religiosos ou políticos. Circunscrevem efemérides, conquistas de direitos, sendo também criadas como marcos de lutas e resistências de determinados grupos. Homenageiam pessoas e eventos, recordam registros, preservam costumes, revelam uma memória que é coletiva. A história da humanidade para alguns povos é contada também através das datas que escolhem relembrar. E como afirma Silva (2002) por trás de todas as comemorações nacionais, encontra-se, portanto, a questão do tempo que se manifesta na sua relação com o passado da História e o presente da memória. (p.125). A escola como lugar de memória e de embates de ideias tem papel importante e fundamental na mediação dessa relação.

Há que se pensar, portanto, como o calendário de datas comemorativas constante do planejamento escolar dialoga com o calendário da vida social e cultural mais ampla. Em que medida esse calendário de datas comemorativas inscreve as crianças no círculo da cultura da humanidade e de seus pares, em que medida se esteriliza quando transformado em "conteúdo escolar"?

A partir da nossa experiência como professoras de Educação e Infantil, e atualmente como formadoras de professoras de 
Educação Infantil, podemos afirmar que o que se presencia nas escolas é,em grande maioria,um planejamento que tenta se "encaixar" em um rol de datas comemorativas às vezes preexistentes ao próprio planejamento do professor. Estas parecem interpelar o planejamento do professor o tempo todo. São como que um relógio a tiquetaquear no nosso encalço. Mesmo compreendendo que todo planejamento precisa de flexibilidade, a fragmentação fica quase sendo a característica do trabalho que gira em torno das datas comemorativas, tendo em vista que têm como foco a mudança das folhas do calendário, sendo, portanto, implacáveis marcadoras do tempo.

Os professores, em seu trabalho cotidiano, são como o anjo da história de que fala Walter Benjamin (1987): amontoam aos pés os restos da materialidade das atividades de cada data comemorativa já vivida - coelhos, cocares, corações, flores, gravatas, coreografias etc. - enquanto seus olhos se escancaram na ansiedade da preparação da outra que se aproxima. Carnaval. Dia Internacional da Mulher. Páscoa. Dia do Índio. Tiradentes. Dia do Trabalhador. Dia das Mães. Abolição da Escravatura. Dia do Meio Ambiente. Festa Junina. Dia da Vovó. Dia dos Pais. Dia do Folclore. Dia do Soldado. Independência do Brasil. Dia da Árvore. Festa da Primavera. Semana do trânsito. Dia das Crianças. Dia do Professor. Halloween. Proclamação da República. Dia da Bandeira. Dia da Consciência Negra. Natal. Seu desejo era poder deter-se para acordar os mortos que se acumulam nessas ruínas: o fim de semana às vezes gasto na preparação de materiais, o tempo condensado da contação de histórias, a conversão do brincar em coreografia administrada, a rouquidão da voz pela experiência diária da pressa da organização, a algazarra das crianças que tudo fazem para esticar a brincadeira, as conversas infantis interrompidas... Mas a tempestade do progresso disfarçada na linearidade de um currículo pautado em datas os impele irresistivelmente a seguir, data a data, ano a ano.

Quantas experiências significativas ficaram às margens desse calendário que, longe de horizontalizar a história, para que os sujeitos envolvidos no fazer educativo pudessem se ver e planejar as utopias possíveis, transformou-se num pêndulo de relógio que marca intermitentemente o compasso do ano letivo? Sensibilizemo-nos com a provocação feita pelo anjo da história: perguntemo-nos sobre os sentidos conferidos ao currículo que efetivamente praticamos.

As questões apresentadas neste texto sugerem reflexões sobre como as instituições de Educação Infantil, em geral, têm priorizado 
as datas comemorativas como base da sua prática pedagógica. E uma reflexão necessária, também, sobre o extenso mercado que se desenvolve nesse filão oferecendo materiais padronizados. Em que medida esses mercados contribuem para alienar o professor em relação ao seu trabalho cotidiano, supondo facilitá-lo?

0 caminho, a nosso ver, continua sendo indagar: se as datas comemorativas são impregnadas de valores e crenças culturalmente importantes, o que, de fato, é indispensável celebrar ou relembrar na escola? Quem escolhe ou define quais datas fazem parte desse currículo? Que contextos das datas comemoradas são compreensíveis para as crianças pequenas? Quais possibilidades de conhecimentos mais amplos as datas permitem trabalhar? 0 trabalho com datas de fato comporta enfrentamentos sobre a exploração comercial, midiática e consumista que muitas dessas datas carregam? As atividades confrontam ou enfatizam estereótipos e preconceitos?

Compreendemos tais perguntas como mobilizadoras e provocadoras, no sentido de fazer pensar novas formas férteis para lidar com as datas comemorativas, não como balizadoras naturalizadas das práticas cotidianas nas escolas, mas inseridas nas possibilidades de construção e ampliação de conhecimento sobre nossa história e nossa cultura.

\section{REFERÊNCIAS BIBLIOGRÁFICAS}

BAKHTIN, Mikhail. Estética da criação verbal. São Paulo: Martins Fontes, 2003.

BARBOSA, Maria Carmen Silveira, OLIVEIRA,Zilma Ramos de. Currículo e linguagem na educação infantil / Brasília: MEC / SEB, 2016. (Coleção Leitura e escrita na educação infantil; v.7).

BARBOSA Maria Carmem e HORN, Maria da Graça. Projetos Pedagógicos na Educação Infantil. Porto Alegre: Artmed: 2009.

BENJAMIN, Walter. Obras escolhidas v. I - Magia e técnica, arte e política. São Paulo: Brasiliense, 1987. 
BRASIL. Ministério da Educação. Conselho Nacional de Educação. Parecer CNE/CEB n. 20, de 11 de novembro de 2009. Revisão das Diretrizes Curriculares Nacionais da Educação Infantil. Brasília, 2009a.

ELIAS, Norbert. Sobre o Tempo. Editora Jorge Zahar, Rio de Janeiro, 1998.

GAGNEBIN, Jeanne-Marie. Sete aulas sobre linguagem, memória e história. São Paulo: Imago, 1997.

GOMES, Cindy R. Sousa, MONTEIRO, Karolina de Jesus. As datas comemorativas na educação infantil: análise das práticas docentes. In: Horizontes - Revista de Educação v. 4, n.7, jan./jun 2016.

KRAMER, Sonia (org) Com a Pré-escola nas mãos: uma alternativa curricular para a educação infantil. São Paulo, Ed Ática, 1999.

MAIA Marta N. V. G. Educação Infantil - Com quantas datas se faz um currículo? Dissertação de Mestrado. Programa de Pós-Graduação em Educação. Pontifícia Universidade Católica do Rio de Janeiro, 2011.

OLIVEIRA, Romilton Batista de. A comemoração de datas histórico-culturais e religiosas na escola: um lugar de memória e de representações. Anais do II Seminário Anual de Ciências Sociaisda UESC, 2009.

OSTETTO, Luciana E. O planejamento na educação Infantil: mais do que a atividade, a criança em foco. In: OSTETTO, Luciana Esmeralda (Org.). Encontros e encantamentos na educação infantil: partilhando experiências de estágios. Campinas/ SP: Papirus, 2000. pp. 175-200.

OSTETTO, Luciana Esmeralda. Danças circulares na educação: Tocar o ser da poesia. Anais da $31^{a}$ Reunião da Associação Nacional de Pós-Graduação em Educação. 2003. Disponível em: http://31reuniao.anped.org.br/1trabalho/ GE01-4412--Int.pdf 
QUEIROZ, Caroline Trapp de. O relógio e o vento. Conversando com crianças sobre o tempo. Rio de Janeiro: Multifoco, 2018.

SANTO AGOSTINHO. Confissões. São Paulo: Abril, 1973. (Coleção Os Pensadores).

SILVA, Helenice Rodrigues da. "Rememoração"/ comemoração: as utilizações sociais da memória. In:Rev. Bras. Hist. vol.22 n.44. São Paulo, 2002. Disponível em: http://www.scielo.br/pdf/rbh/v22n44/14006.pdf (Acesso em 12/08/2018).

SOUSA, Maria de Fátima Guerra de. Para além dos coelhos e corações: reflexões sobre a prática pedagógica do educador infantil. Brasilia, DF: Linhas Críticas, Revista Faculdade de Educação UNB. v.6,n.10, jan. a jun. 2000. Disponível em: http://periodicos.unb.br/index.php/linhascriticas/article/ view/6694/5405(Acesso em 12/08/2018).

TOMAZZETTI Cleonice Maria, PALAURO Marisa Mattos. Datas comemorativas na educação infantil: quais sentidos na prática educativa? In: Crítica Educativa - Programa de Pós-Graduação em Educação UFSCar, Sorocaba/SP, v. 2, n. 2, p. 150-164, jul./dez2016. Disponível em: http://www. criticaeducativa.ufscar.br/index.php/crit icaeducativa/ article/view/87/229(Acesso em 12/08/2018).

Recebido: 20/09/2018

Revisto: 05/11/2018

Aceito: 15/10/2018 